\title{
Legal Counseling On Civil Rights Due To Marriage Different Religions In Ogan Ilir Regency - South Sumatra Province
}

\author{
Junaidi $^{1}$, Mila Surahmi ${ }^{*}$, Desmawaty Romli ${ }^{3}$, Citra Dewi Saputra ${ }^{4}$, Liza Nofianti ${ }^{5}$ \\ 1, 2, 3, 4, 5 Fakultas Hukum,Universitas Sjakhyakirti Palembang, Indonesia \\ *Corresponding Author : \\ E-mail : milamimi@unisti.ac.id
}

\begin{abstract}
Interfaith marriage is a marriage bond between a man and a woman who have different beliefs and religions. In principle, interfaith marriages are prohibited by every religious teaching. Every religious instruction requires a marriage bond to be carried out in a bond of the same faith (one religion). Based on Article 2 paragraph (1) of Law Number 1 of 1974 concerning Marriage, it is explained that a marriage is considered valid if it is carried out according to their respective religions and beliefs. Legal problems arise due to interfaith marriages, including the validity of marriages that give rise to rights and obligations between husband and wife and children's status due to interfaith marriages on their inheritance rights. Interfaith marriages occur in society but are usually covered up. In the case of interfaith marriages in Ogan Ilir Regency, our Community Service Team, Faculty of Law, Sjakhyakirti University conducted legal counseling to understand the legal consequences of interfaith marriages, especially regarding the validity of marriages, child status, and inheritance.
\end{abstract}

Keywords: Legal Consequences of Marriage, Interfaith Marriage, Child Status and Inheritance of Different Religions.

\section{INTRODUCTION}

Marriage is an important event for human relations, which aims to produce offspring[1]. Marriage is the essential capital in forming a family, the smallest part but the core of the center of national life. Birth is the initial process of human presence due to Marriage, raising, and getting an education to have good character and dignity[2].Indonesia is a pluralistic society, where there are various forms of culture and different customs that are influenced by their respective religions and beliefs. It is one of the causes of the differences in the rules. Until now, the customs that we can see in our marriages, where marriage procedures are still influenced by culture, religion, and beliefs in the community environment. One region and another have different customs[3]. Marriage is about the relationship between their respective partners and regulates religious, social, and legal issues. Each religion has its own rules regarding Marriage. Therefore, it must be obeyed and obeyed by each of its adherents who will enter into Marriage. In Marriage, legal problems often arise due to the relationship between humans[4].Marriage is a physical and spiritual bond between a man and a woman. A marriage is valid if it is under the legal rules of their respective religions and beliefs as regulated in Article 2 paragraph (1) of Law Number 1 of 1974 concerning Marriage. It shows that every Marriage in Indonesia has gone through the marriage institution of their respective religions and adheres to the rules of Marriage in their respective religions[5].

With the plurality of society in Indonesia, marital problems will arise, especially in applying Article 2 paragraph (1) of Law Number 1 of 1974 concerning Marriage. There must be marriages held of different religions and beliefs.Law Number 1 of 1974 concerning Marriage has regulated in such a way regarding marital problems. but it does not explicitly address marriages caused by differences in religion, and interfaith Marriage is an inner and outer bond of a man and woman who have different religions and beliefs[6]. Interfaith marriages are not new in Indonesian society, which has various customs, religions, and beliefs. This Marriage often occurs in various levels of society and has been going on for a long time. Therefore, interfaith marriages in Indonesia experience controversy in society. Many people think that the problem is due to Article 57 of Law Number 1 of 1974 concerning Marriage, which only regulates mixed marriages, the 
Marriage only describes marriages that taken place between couples subject to different legal regimes in Indonesia due to the distinct nationalities of the parties, and not based on religion or belief differences between the parties.Marriages that take place due to these religious differences, all religions in Indonesia do not recognize it or are invalid. Problems arising due to Marriage due to different religions will impact the status of children and their inheritance rights. Religious differences are a factor that prevents a person from getting inheritance rights from his parents.

\section{METHODS}

Interfaith weddings occur in Indonesia at large, but in Ogan Ilir Regency, in particular, there is a need for counseling and community service activities to provide education concerning these marriages. This legal counseling activity to the community was carried out in Ogan Ilir Regency, involving all village officials, starting from the Village Head, Village Secretary, Community Leaders, Religious and Community Leaders. The methods applied in carrying out community service through legal counseling are:

1) Cooperating with Ogan Ilir Regency Government to prepare the time, place, participants from various village apparatus and community institutions for implementation. In this activity, legal advice and related education are provided regarding the civil rights of the community following interfaith marriages;

2) Prepare various materials or materials related to marriage law, especially problems in interfaith marriages;

3) This legal counseling, apart from lecturers at the Faculty of Law, Sjakhyakirti University, also involves 2 (two) students as master of ceremonies;

4) The activity involves lectures in which the presenters each present their material, followed by a "question and answer" session with the participants.

\section{RESULT AND DISCUSSION}

This legal counseling activity is part of the Community Service of the Faculty of Law, Sjakhyakirti University, Palembang. It is carried out in Ogan Ilir Regency, located in the South Sumatra LPMP Building, Jalan Lintas Sumatra, Number 14 Indralaya Mulia, Indralaya District, Ogan Ilir Regency, South Sumatra Province. The participants in the legal counseling consisted of various groups ranging from all village officials, non-governmental organizations, community leaders, religions, and officials who were all within the Ogan Ilir Regency Government, South Sumatra.

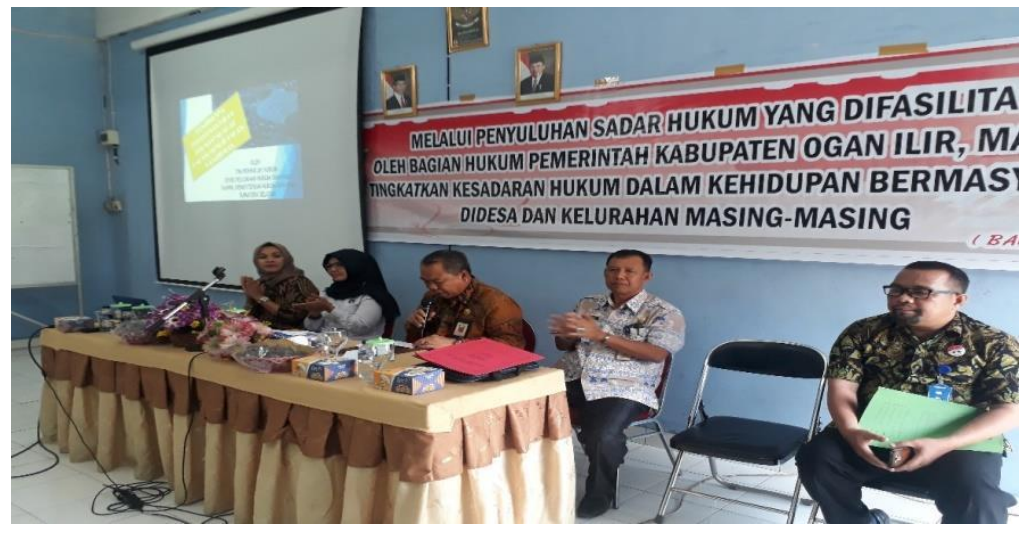

Fig 1. Opening of Counseling by Regent of Ogan Ilir and Speech from the Head of Law

Documentation of the Faculty of Law, Sjakhyakirti University

This legal counseling began with the opening conducted by the Master of Ceremony. In the opening ceremony, the Head of the Legal Division of the Ogan Ilir Regency Government gave directions and objectives to implement this activity. Furthermore, the legal counseling activity was officially opened by the Regent, Ogan Ilir, who welcomed the arrival and arrival of the team of presenters in providing legal understanding regarding the community's civil rights.Immediately following the opening remarks by the 
Ogan Ilir Regency Government, the Law Counseling Team of the Law Faculty of Sjakhyakirti presented material, and there was discussion and questions and answers.
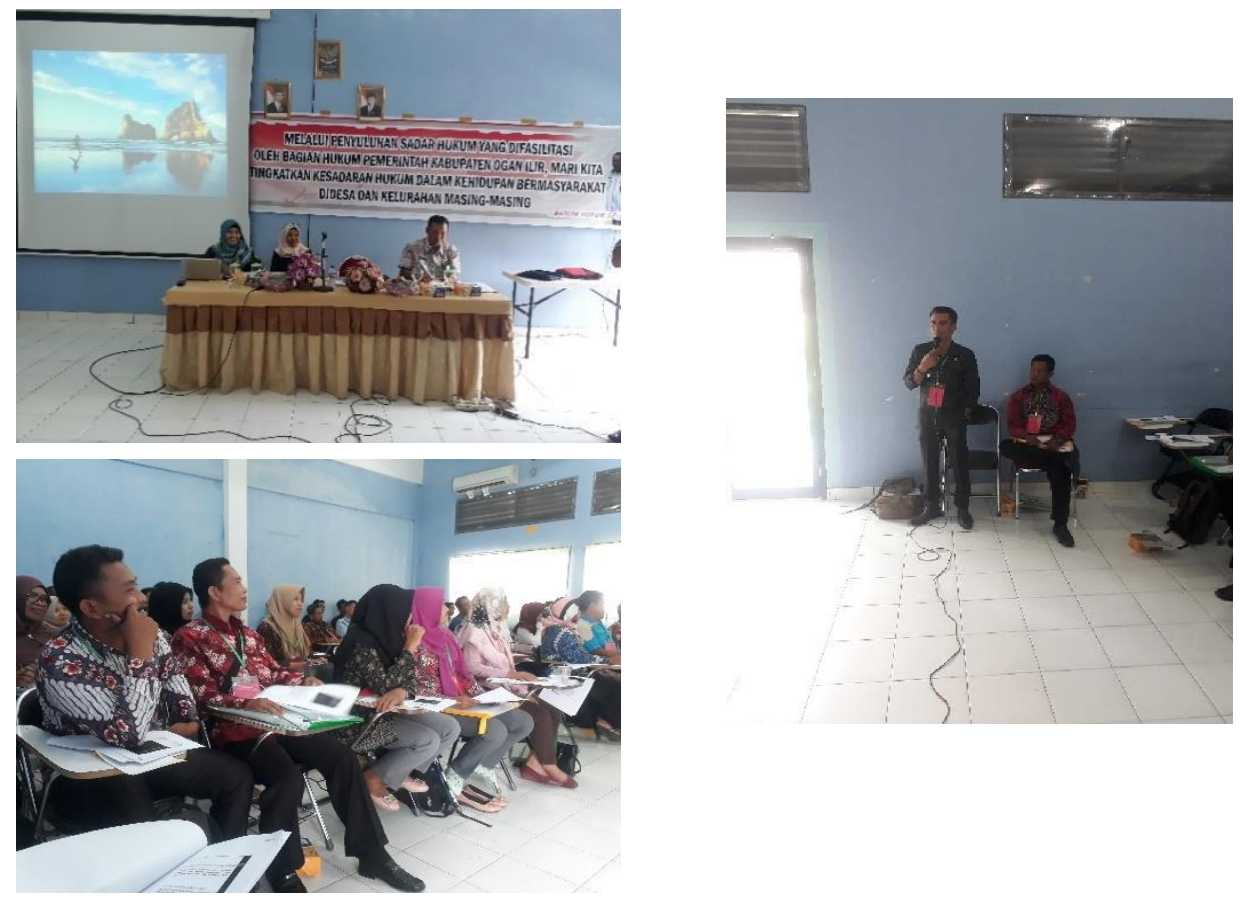

Fig 2. Delivery of material and discussion questions and answers.

Documentation of the Faculty of Law, Sjakhyakirti University

\section{Consequences of Interfaith Marriage Law}

Marriage is a religious activity that is part of worship and has legal actions, especially in Marriage Law. Indonesia is a pluralistic country consisting of tribes, customs, cultures, and religions that cannot limit humans as social beings who cannot live without other humans. Therefore, there must be an understanding of the meaning of relationships, especially in forming family ties, so that rights and obligations arise [7]. Protracted polemics without a clear and complete solution in Indonesia, one of which is an interfaith marriage. Although Indonesia already has Law Number 16 of 2019 concerning Amendments to Law Number 1 of 1974 concerning Marriage which is the legal basis for Marriage. In principle, the application of the law has many shortcomings, especially in the explicit regulation of interfaith marriages that are not explicitly regulated [8].Interfaith marriages occur due to unavoidable social fabrics. In the Marriage Law, it is not explicitly regulated, and this will result in frequent occurrences because the Indonesian people, especially their citizens, have religious pluralism[9]. The legal consequences of interfaith marriages are:

\section{Legal Consequences on Marital Status}

Interfaith Marriage in Indonesia is a problem in itself that needs to be solved as well as possible. For the ratification of interfaith marriages, there is no explicit legal arrangement. It is evident in the practice of many couples who marry by following their partner's religion to obtain recognition and ratification of Marriage. When it has been legalized, then they return to their religion again. There is also a marriage abroad, then return to Indonesia to be registered[10]. Regulations regarding Marriage are contained in Article 2 paragraph (1) of Law Number 1 of 1974 concerning Marriage which explains that marriages are declared valid according to the rules and procedures of their respective religions, and Article 44 of the Compilation of Laws prohibits interfaith marriages between a Muslim and a non-Muslim[11]. The legal umbrella in Marriage is crucial because religious procedures determine whether or not a marriage is allowed. If the provisions in religion do not allow a marriage, then state law does not allow it. Therefore, interfaith marriages are allowed or not depending on the provisions of their respective religions[12].It is in line with the Compilation of Islamic Law, which categorizes inter-religious marriages in the chapter on the prohibition of Marriage. Article 40 letter (c) states that it is forbidden to marry a man to a woman who is not Muslim. As 
well as the authority in determining interfaith marriages by the court in Article 35 letter (a), if reviewed, is contrary to Law Number 1 of 1974 concerning Marriage which does not explicitly prohibit interfaith marriages[13].Among the many ways to cope with interfaith marriages, 2 (two) main ways can be used[14]:

1) By converting religion to obtain legal recognition, then returning to their religion again. The case, however, constitutes legal smuggling because the marriage law has been circumvented. Do not do this method.

2) Registering interfaith marriages at the Civil Registry Office based on the Supreme Court Decision Number $1400 . K / \mathrm{Pdt} / 198$.

All religions in Indonesia prohibit interfaith marriages. Article 44 of the Compilation of Islamic Law expressly prohibits interfaith marriages between Muslim men and non-Muslim women prohibited. It is also prohibited by Christianity for its adherents to be prohibited from marrying non-Christians. Therefore, interfaith marriages are prohibited by all religions in Indonesia. It is also prohibited by Law Number 1 of 1974 concerning Marriage, resulting in invalid marriage [15].According to Budi Handrianto, Marriage performed by a couple of different religions is haram. To achieve the desired happiness starts from harmony in building a household. Therefore, in the household, there must be a cooperative relationship between husband and wife. It will not be achieved if there are religious differences in realizing a happy household [16].In Indonesia, Marriage between couples who belong to different religious groups is not regulated in detail by the Marriage Law. Marriage is valid if it is performed according to the principles of religion and belief. Article 2 paragraph (1) of Law Number 1 of 1974 concerning Marriage stipulates that the validity of a marriage depends solely on the guidance of each religion. The religious direction of each party will determine whether interfaith marriages are permitted or not. For example, Islam forbids women from marrying non-Muslim men (Al Baqarah: 221), as well as Christian religious guidance interfaith marriages are prohibited (Corinthians 6:14-18).Law Number 1 of 1974 is the national legal basis for marriages performed in Indonesia. This Marriage Law provides limitations on the civil rights of the community. If a couple of different religions carries out a marriage, then what determines whether a marriage is legal or not is the religion that each adheres to.

\section{Legal Consequences on the Status and Position of Children}

According to Article 42 of Law Number 1 of 1974, it is explained that a legitimate child is a child born in or as a result of a legal marriage. It follows the provisions of Article 99 of the Compilation of Islamic Law, which explains that a legitimate child is a child born in or as a result of a legal marriage. Based on the provisions described above, it can be determined that whether a child is legal or not depends on whether or not a marriage is legal. Therefore, children resulting from marriages of different religions are illegitimate children or illegitimate children. Therefore, the child does not have a civil relationship with his father and only has a civil relationship with his mother and mother's family. It follows Article 43 paragraph (1) of Law Number 1 of 1974 concerning the 100 Compilation of Islamic Law, which explains that children born out of wedlock only have nasab with the mother and her mother's family.

\section{Legal Consequences on Inheritance}

According to Wirjono Prodjodikoro, "inheritance is a matter of whether and how various rights and obligations regarding a person's wealth at the time of his death will be transferred to those who are still alive" [17]. "In other terms, inheritance in Islam is also called fara'idh, which is a certain part that is divided among all who are entitled to receive it" [18].According to Ahmad Azhar Basyir, inheritance according to Islamic law is the process of transferring the inheritance of someone who has died, both in the form of tangible objects and material rights, to his family, who is declared entitled by law[19]. According to Amir Syarifuddin, Islamic inheritance law can be interpreted as a set of written regulations based on Allah's revelation and the Sunnah of the Prophet regarding the transfer of property or tangible assets from the dead to the living, which is recognized and believed to be valid and binding for all Muslims. [20].Article 171 letter c of Presidential Instruction Number 1 of 1991 concerning the Compilation of Islamic Law stipulates that an heir is a person who at the time of death is related by blood or marriage to the heir, is Muslim, and is not prevented by law from becoming an heir. "According to Ahmad Rofiq, this provision is also intended to 
deny the existence of barriers to mutual inheritance. However, these provisions are still general" [21].The Compilation of Islamic Law does not explicitly state the religious differences between heirs and heirs as barriers to inheriting.

The compilation only confirms that the heir is Muslim at the time of the heir's death (Article 171 letter $\mathrm{c}$ of the Compilation of Islamic Law). Article 172 of the Compilation of Islamic Law states that an heir is considered Muslim if it is known from an identity card or confession or practice or testimony, while for a newborn baby or child who is not yet an adult, religion according to his father or environment. Meanwhile, the identity of the heir is only explained in the general provisions of letter b, namely the person who at the time of death or who is declared dead based on a court decision, is Muslim, leaves heirs and inheritance (Article 171 of the Compilation of Islamic Law). What is meant by different religions here is between Muslims and non-Muslims. Religious differences that are not Muslim, for example, between Christians and Buddhists, are not included in this definition."Muslims do not take inheritance from infidels, and vice versa"[22]. The four priests agreed upon this law. "Said ibn Musaiyab and an-Nakha'i narrate that Muslims take inheritance from infidels, not the other way around, just as Muslims may marry infidel women, Muslim women should not marry infidel men"[23].

\section{CONCLUSION}

Marriage of different religions is prohibited by Law Number 1 of 1974 concerning Marriage because such marriages are not carried out according to the laws of each religion and belief. A result of interfaith marriages that have been held in the community is invalid because they deviate from the intent of the provisions of Article 2 paragraph (1) and Article 8 point (f) of Law Number 1 of 1974 concerning Marriage. The illegitimate marriage affects the status and position of the child. Children born in interfaith marriages are illegitimate children because the marriage of both parents is not legal. The child has no legal relationship with his father. But only with the mother and her mother's family. It follows Article 43 paragraph (1) of Law Number 1 of 1974 concerning Marriage and Article 100 of the Compilation of Islamic Law. It also results in differences in religion, so they do not inherit each other.

\section{ACKNOWLEDGMENTS}

This Legal Counseling activity to the Community in Ogan Ilir Regency is part of the Community Service Program at the Faculty of Law, Sjakhyakirti University. This activity can run smoothly and well, thanks to the help of the parties. Therefore we would like to thank:

1) The Government of Ogan Ilir Regency, in this case, the Regent, who has facilitated this activity;

2) The Head of Legal Affairs of the Ogan Ilir Regency Government who has provided a place and brought the participants;

3) All Ogan Ilir Regency Government Officials, Village Apparatus, Community Leaders, NonGovernmental Organizations, and the entire Ogan Ilir Regency community.

\section{REFERENCES}

[1] Soedharyo, Soimin, Hukun Orang dan Keluarga Perspektif Hukum Perdata Barat/BW, Hukum Islam, dan Hukum Adat, Jakarta : Sinar Grafika, 2004, hlm. 3

[2] Junaidi dan Mila Surahmi, Dispensasi Perkawinan di Bawah Umur dalam Perspektif Undang-Undang Nomor 16 tahun 2019 dan Undang-Undang Nomor 35 tahun 2014, Prosiding Nasional Universitas Suryakancana "ReOrientasi Pendidikan Hukum Berkarakter di Era Industri 4.0”, 2020, hlm. 73

[3] A. Syamsul Bahri dan Adama, Akibat Hukum Perkawinan Beda Agama Menurut Undang-Undang Nomor 1 tahun 1974 tentang Perkawinan, Al-Syakhshiyyah : Jurnal Hukum Keluarga Islam dan Kemanusiaan, Vol.2 No. 1, Juni 2020, hlm.76

[4] Junaidi dan M. Martindo Merta, Perkawinan Beda Agama dan Akibat Hukum Kewarisan dalam Perspektif Hukum Islam, Prosiding Internasional "Strenghthening the Islamic Diplomacy in Worldwide", No.1, 2020, hlm. 269

[5] Wedya Laplata, Pelaksanaan Perkawinan Beda Agama dalam Perspektif Yuridis (Studi Kasus Putusan di Pengadilan Negeri Surakarta), Jurnal Jurisprudence, Vol. 4 No. 2, Desember 2014, hlm. 76 
[6] Soedharyo Soimin., Hukum Orang dan Keluarga. Jakarta: Sinar Grafika. 2002, hlm. 3

[7] Ni Kadek Oktaviani, I Ketut Widia dan I Ketut Sukadana, Status Mewaris terhadap Anak yang Lahir dari Perkawinan Beda Agama, Jurnal Analogi Hukum, Vol. 3, No. 1, 2021, hlm. 29

[8] Jane Marlen Makalew, Akibat Hukum Perkawinan Beda Agama di Indonesia, Jurnal Lex-Privatum, Vol. 1 No. 2, April-Juni 2013, hlm. 133

[9] Tengku Erwinsyahbana, Aspek Hukum Perkawinan Antar Agama dan Problematika Yuridisnya, Refleksi Hukum : Jurnal Ilmu Hukum, Vol. 3 No. 1, Oktober 2018, hlm. 99

[10] Anggreini Carolina Palandi, Analisa Yuridis Perkawinan Beda Agama di Indonesia, Jurnal Lex Privatum, Vol. 1 No. 2, April-Juni 2013, hlm. 204

[11] A. Syamsul Bahri dan Adama, Op.cit, hlm. 84

[12] Nur Asiah, Kajian Hukum terhadap Perkawinan Beda Agama menurut Undang-Undang Perkawinan dan Hukum Islam, Jurnal Hukum : Samudra Keadilan, Vol. 10 No. 2, Juli-Desember 2015, hlm.207

[13] Ibid

[14] Jarwo Yunu, Aspek Perkawinan Beda Agama Di Indonesia, Jakarta : CV. Insani, 2005, hlm. 11.

[15] Hanum Farchana Devi dan Mastur, Tinjauan Hukum Perkawinan Beda Agama dan Akibat Hukumnya menurut Undang-Undang Nomor 1 tahun 1974 tentang Perkawinan, Qistie : Jurnal Ilmiah Ilmu Hukum, Vol. 11 No. 1 , Mei 2018, hlm. 145

[16] Budi Handrianto, Pernikahan Beda Agama dalam Syari'at Islam, Jakarta : PT. Kairul Bayan, 2003, hlm. 20

[17] Wirjono Prodjodikoro, Hukum Warisan di Indonesia, Bandung: Sumur Bandung, 2006, hlm. 13.

[18] Beni Ahmad Saebani, Fiqh Mawaris, Bandung: Pustaka Setia, 2014, hlm. 13.

[19] Ahmad Azhar Basyir, Hukum Waris Islam, Yogyakarta: UII Press, 2004 hlm. 132

[20] Amir Syarifuddin, Hukum Kewarisan Islam, Jakarta: Prenada Media, 2004, hlm. 6

[21] Ahmad Rofiq, Hukum Islam di Indonesia, Jakarta: Raja Grafindo Persada, 2004, hlm. 402.

[22] Syekh Mahmud Syalthut, Fiqih Tujuh Madzhab, terjemahan Abdullah Zakiy al-Kaaf, Bandung: CV Pustaka Setia, 2000, hlm.293

[23] TM.Hasbi Ash Shiddieqy, Hukum-Hukum Fiqih Islam, Tinjauan antar Mazhab, Semarang: PT.Pustaka Rizki Putra, 2001, hlm. 310 